\title{
PELAYANAN TERPADU KORBAN KEKERASAN TERHADAP PEREMPUAN DI KOTA SEMARANG
}

\author{
Marsha Ayunita Irawati, M.Si ${ }^{1}$
}

\begin{abstract}
This study aims to analyze the effort that has been done by Women Empowerment, Child Protection and Family Planning Bureau (BP3AKB) of Semarang city. This is a qualitative research. The technique of collecting data employed interviews, documentation, book references, and related agencies official documents. The results showed that: a) SERUNI service center is not optimal, can be seen from number of violence against women still remains high from year to year. b) Limited mentor in SERUNI service center that were lacking, budget to handling are less dan facilities and infrastructure to reporting and assistance is good enough. c) Factors that affect the handling of violence against women in Semarang City is the quantity of human resources are inadequate, the commitment Integrated SERUNI service centers to provide maximum services to victims of violence, lack of budget assistance, facilities and infrastructure SERUNI service centers inadequate, lack of awareness and community participation in the elimination of violence against women, characteristics abusers are difficult to handle, and Semarang as destination for job seekers.
\end{abstract}

Keywords: Public Service, Violence Against Women, Affecting Factors

\begin{abstract}
ABSTRAK
Penelitian ini bertujuan untuk menganalisis upaya yang telah dilakukan Badan Pemberdayaan Perempuan, Perlindungan Anak dan Keluarga Berencana (BP3AKB) Kota Semarang. Penelitian ini menggunakan pendekatan kualitatif. Teknik pengumpulan data melalui wawancara, dokumentasi, referensi buku, dan dokumen instasi. Hasil penelitian terhadap penanganan korbankekerasan perempuan di Kota Semarang menunjukkan a) Pelayanan pada Pusat Pelayanan Terpadu SERUNI masih belum optimal, dapat dilihatdari masih banyaknya jumlah angka kekerasan terhadap perempuan di Kota Semarang dan bahkan cenderung meningkat dari tahun ketahun b) BP3AKB dalam menangani korban kekerasan terhadap perempuan yang bekerja dengan lembaga-lembaga lainnya seperti Rumah Sakit, Puskesmas, Kepolisian, Lembaga Bantuan Hukum, Badan Pemberdayaan Masyarakat, Dinas Pendidikan, dan Lembaga Swadaya Masyarakat c) Faktor yang mempengaruhi penanganan kekerasan terhadap perempuan di Kota Semarang yaitu kuantitas SDM yang kurang, komitmen pelayanan kepada korban kekerasan, minimnya anggaran pendampingan, sarana dan prasarana kurang memadai, kurangnya kesadaran dan peran serta masyarakat dan karaktersistik pelaku kekerasan yang sulit ditangani.
\end{abstract}

Kata kunci: Pelayanan publik, kekerasan terhadap perempuan, faktor yang mempengaruhi

${ }^{1}$ Dosen, Jurusan Ilmu Adminsitrasi Negara, Fakultas Ilmu Sosial, Universitas Negeri Yogyakarta, email:marsha.ayunita@yahoo.com 


\section{PENDAHULUAN}

Manusia sejak dilahirkan telah memiliki hak yang disebut Hak Asasi Manusia.Prinsip-prinsip yang mengatur tentang Hak Asasi Manusia (HAM) terdapat dalam Deklarasi Universal hak asasi manusia yang diterima dan diumumkan oleh Majelis Umum PBB pada tanggal 10 Desember 1948 melalui resolusi 217 A (III).Deklarasi Universal Hak Asasi Manusia menjadi standar umum bagaimana keberhasilan semua bangsa dan semua negara untuk memperjuangkan dalam penegakan martabat manusia.

Kebijakan pemberdayaan perempuan telah mengalami kemajuan di tingkat nasional terutama sejak diratifikasinya Konvensi Penghapusan Bentuk Diskriminasi terhadap Perempuan melalui UU No. 7 tahun 1984. Terdapat berbagai upaya dalam bentuk peraturan perundangan, kelembagaan dan penganggaran sudah dilakukan, diantaranya yaitu UU No. 23 tahun 2004 tentang Penghapusan Kekerasan Dalam Rumah Tangga, UU No. 21 tahun 2007 tentang Pemberantasan Tindak Pidana Perdagangan Orang, Instruksi Presiden No. 9 tahun 2000 tentang Pengarusutamaan Gender (PUG), Peraturan Mentri Dalam Negri No. 15 Tahun 2008 tentang Pedoman
Pelaksanaan Pengarustamaan Gender di Daerah. Dari perundang-undangan tersebut membahas diantaranya tentang Gender.

Tindak kekerasan yang mengandung faktor jenis kelamin dikenal dengan istilah Gender Violence. Pada kecenderungan kasus kekerasan terhadap perempuan yang terjadi di banyak aspek kehidupan, banyaknya kasus kekerasan disebabkan korban mempunyai hambatan serius dalam hal keadilan, diantaranya adalah sedikitnya korban yangmelapor karena takut menanggung aib, ataupun adanya ancaman apabila melaporkan kasusnya, selain karena besarnya kekuasaan dan pengaruh 'nama besar' dari tokoh menyebabkan penanganan yang tertutup. Data Kasus Masuk Legal Resources Center untuk Keadilan Jender dan Hak Asasi Manusia memperkirakan adanyakecenderungan kriminalisasi terhadap perempuan korban kekerasan, diantaranya 7 perempuan korban kekerasan berbasis gender yang melaporkan kasusnya justru 'terjebak' kepada kriminalisasi terhadap dirinya. Pelaku yang merupakan tokoh publik sangat sulit dijerat hukum.Kasus yang semula melaporkan pelaku justru tidak terselesaikan, dan beralih pada penyangkaan terhadap korban.Sementara 
itu kecenderungan diskriminasi dan kekerasanterhadap perempuan dalam konteks perempuan desa dan migrasi nampak pada data monitoring Legal Resources Center untuk Keadilan Jender dan Hak Asasi Manusia 2011 yang menyebutkan terdapat 169 perempuan buruh migran asal Jawa Tengah mengalami kekerasan.

Pelayanan publik menurut UndangUndang Nomor 25 Tahun 2009 adalah kegiatan atau rangkaian kegiatan dalam rangka pemenuhan kebutuhan pelayanan sesuai dengan peraturan perundangundangan bagi setiap warga negara dan penduduk atas barang, jasa, dan/atau pelayanan administratif yang disediakan oleh penyelenggara pelayanan publik.Sedangkan menurut Gronroos dalam Ratminto (2010: 2) menjelaskan bahwa pelayanan adalah suatu aktivitas atau serangkaian aktivitas yang bersifat tidak kasat mata (tidak dapat diraba) yang terjadi sebagai akibat adanya interaksi antara konsumen dengan karyawan atau hal-hal lain yang disediakan oleh perusahaan pemberi pelayanan yang dimaksudkan untuk memecahkan permasalahan konsumen atau pelanggan.

Kota Semarang adalah daerah di Jawa Tengah dengan jumlah kasus yang tertinggi yaitu mencapai 121 kasus, kemudian Kabupaten Demak dan Kabupaten Semarang. Berdasarkan data yang ada pada Badan Pemberdayaan Perempuan, Perlindungan Anak dan Keluarga Berencana Provinsi Jawa Tengah dapat dilihat enam besar Kabupaten/Kota di Jawa Tengah dengan jumlah kasus kekerasan terhadap perempuan tertinggi pada tahun 2012 sebagaiberikut.

\section{Tabel 1. Jumlah Kasus Kekerasan Di Jawa Tengah Tahun 2012}

\begin{tabular}{|c|c|c|}
\hline No & Kabupaten/Kota & Jumlah Kasus \\
\hline 1 & Kota Semarang & 121 \\
\hline 2 & Kabupaten Demak & 34 \\
\hline 3 & Kabupaten Semarang & 25 \\
\hline 4 & Kabupaten Wonogiri & 17 \\
\hline 5 & Kabupaten Kendal & 15 \\
\hline 6 & Kabupaten Pekalongan & 13 \\
\hline
\end{tabular}

Sumber: Badan Pemberdayaan Perempuan, Perlindungan Anak dan Keluarga Berencana Provinsi Jawa Tengah 2012

Gambaran umum lainnya berkaitan dengan ditemukannya berbagai kecenderungan kasus kekerasan perempuan yang terjadi di Kota Semarang yaitu banyaknya jumlah kasus kekerasan perempuan padahal sudah terdapat kebijakan penanganan perempuan korban kekerasan di Kota Semarang, terjadinya kekerasan terhadap perempuan dalam konteks perempuan desa dan migrasi, Kurangnya sumber 
daya manusia untuk memberikan pelayanan kepada masyarakat, Terus bertambahnya jumlah kekerasan perempuan dari tahun ke tahun, kurang seriusnya aparat pemerintah, aparat penegak hukum, institusi pendidikan dan stakeholder dalam menegakkan terpenuhinya hak perempuan korban kekerasanatas pemulihan, kebenaran dan keadilan.

Ditengah banyaknya jumlah kekerasan terhadap perempuan di Kota Semarang mendorong pemerintah membentuk Pusat Pelayanan Terpadu Penanganan Kekerasan terhadap Perempuan dan Anak Berbasis Gender "SERUNI" Kota Semarang di setiap kecamatan yang terjadi kasus kekerasan dalam rumah tangga maupun kekerasan terhadap anak.

Oleh karena itu, penulis tertarik untuk meneliti lebih lanjut pelayanan terpadu yang diberikan kepada korban kekerasan yang dialami perempuan, peran stakeholder dalam penanganan kekerasan terhadap perempuan di Kota Semarang serta faktor yang berpengaruh dalam pelayanan terpadu korban kekerasan terhadap perempuan di Kota Semarang.

\section{METODE PENELITIAN}

Tipe penelitian ini adalah deskriptif kualitatif, difokuskan di Kota Semarang karena di Kota Semarang memiliki jumlah kasus yang tertinggi di Jawa Tengah. Penelitian dilakukan di Badan Pemberdayaan Perempuan Perlindungan Anak dan Keluarga Berencana Kota Semarang dan Pusat Pelayanan Terpadu Seruni dengan memfokuskan pada pelaksanaan pelayanan terpadu dalam hal penanganan tindak kekerasan terhadap perempuan di Kota Semarang. Penelitian dilakukan pada bulan Juli-Desember 2013. Teknik pengumpulan data dalam penelitian ini dilakukan melalui wawancara, observasi dan dokumentasi. Informan dalam penelitian ini yaitu Wakil Ketua BP3AKB Kota Semarang, Kader Pendamping Perempuan dan Korban kekerasan.

Data dan informasi yang diperoleh kemudian di analisis secara deskriptif kualitatif untuk menggambarkan pelayanan terpadu yang diberikan kepada korban kekerasan terhadap perempuan dan mengidentifikasi faktor-faktor yang mempengaruhi pelaksanaan pelayanan yang diberikan kepada korban kekerasan di Kota Semarang.

\section{HASIL DAN PEMBAHASAN}

Kekerasan terhadap perempuan dan anak di Jawa Tengah dari tahun ke tahun semakin meningkat, baik jumlah, bentuk, maupun modusnya. Sebagai 
gambaran, dari 18 PPT di Jawa Tengah yang melaporkan kasus kekerasan dan yang tangani oleh PPT di wilayahnya dan dari laporan KPPA Provinsi Jawa Tengah, selama tahun 2007 tedapat 612 kasus KDRT, 176 Kasus Pemerkosaan dan 27 kasus Traficking. Kasus-kasus ini adalah kasus yang terpantau dan terlaporkan. Masih banyak kasus
PKDRT, serta UU No 21 tahun 2007 tentang PTPPO, maka Pemerintah Provinsi Jawa Tengah membentuk pelayanan terpadu korban kekerasan yang diatur dengan PeraturanDaerah nomor 3 tahun 2009 tentang Penyelenggaraan Perlindungan Korban Kekerasan Berbasis Gender dan Anak dan di Kota Semarang berdasarkan Surat Keputusan Walikota

Tabel 1Mekanisme Pelayanan Rujukan bagi Korban Kekerasan Perempuan

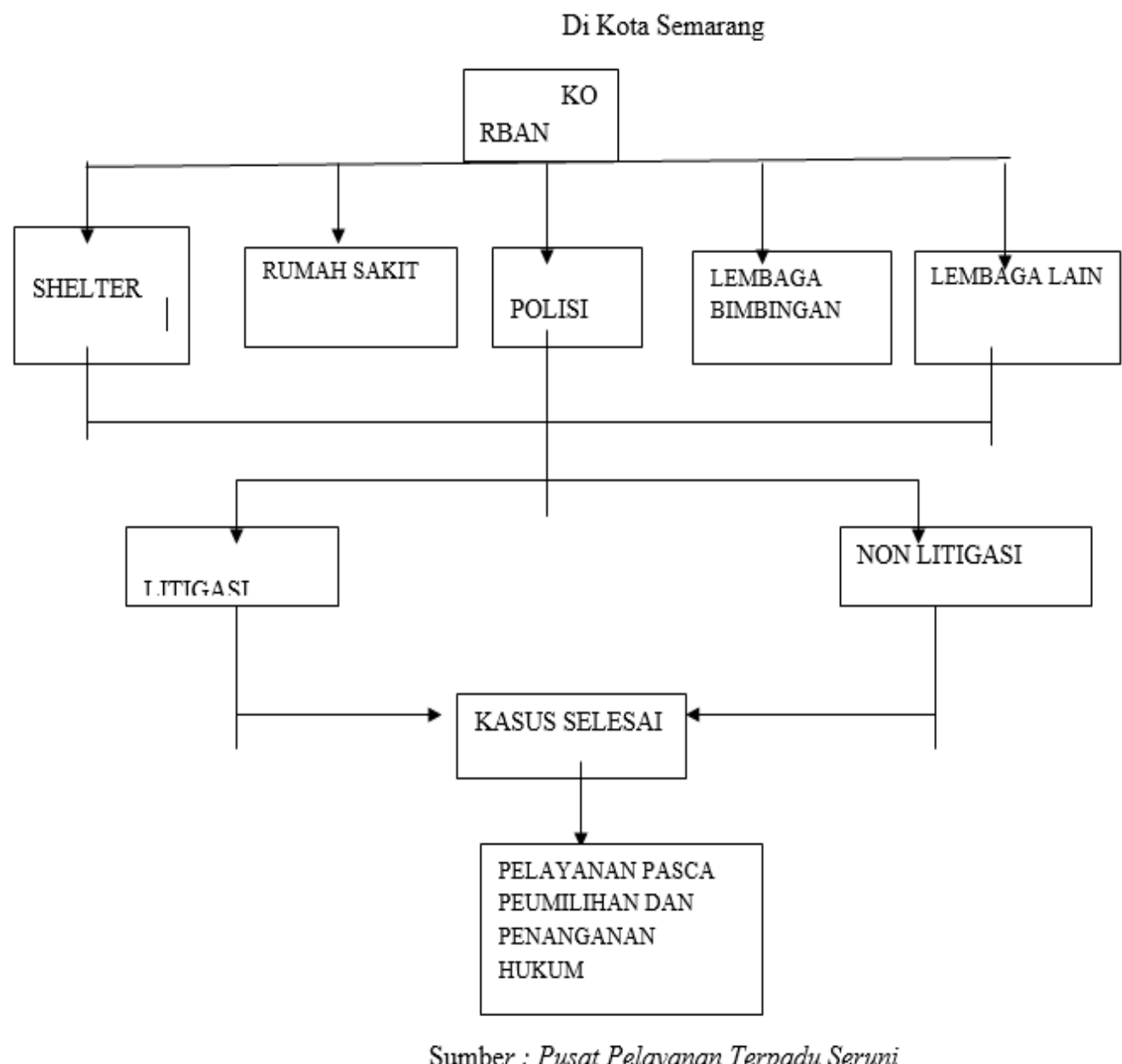

kekerasan lainnya yang tidak tercatat dan terlaporkan.Sebagai bentuk komitmen dan kewajiban yang diamanatkan UU No 23 Tahun 2002 tentang Perlindungan Anak, UU No 23 tahun 2004 tentang
Np. 463/A. 023 tanggal 12 Febuari 2009 dibentuk Pusat Pelayanan Terpadu bagi Perempuan dan Anak yang Berbasis Gender "SERUNI" Kota Semarang. 
Pusat pelayanan terpadu SERUNI merupakan Pusat Pelayanan Terpadu Penanganan Kekerasan Terhadap Perempuan dan anak Berbasis Gender di Kota Semarang, yang mengandung artiSemarang Terpadu Rumah Perlindungan Untuk Membangun Nurani dan Cinta Kasih Insani disingkat “SERUNI", lahir tanggal 1 Maret 2005 hasil kesepakatan bersama peserta Pelatihan dan Rapat Koordinasi Lintas Sektoral yang diselenggarakan oleh Tim TOT Pendidikan HAM Berperspektif Gender Jawa Tengah bekerjasama dengan Komisi Nasional Anti Kekerasan Terhadap Perempuan (KOMNAS PEREMPUAN), yang dihadiri oleh perwakilan dari unsur Pemerintah, Akademisi, LSM, Praktisi dan Aktifis Perempuan.

Jenis pelayanan yang diberikan Pusat Pelayanan Terpadu (PPT) meliputi, pelayanan medis,

(RSUD TugurejoSemarang, RSUD Aminogondo Hutomo di Semarang), Pelayanan Psikologis, Pendampingan Rohani, Fasilitas Pemulangan Korban, Perlindungan Sementara di Shelter, Pendampingan Hukum pada kasus banding, Konsultasi Hukum, dll.

Melihat kondisi kekerasan perempuan di Kota Semarang kegiatan yang dilakukan adalah meliputi sistem penanganan yang dilakukan melalui pelaporan dan penanganan di Badan Pemberdayaan Perempuan Perlindungan Anak dan Keluarga Berencana Kota Semarang, Pusat Pelayanan Terpadu Seruni serta keterlibatan instansi lain dalam penanganan perempuan.

Sistem Penanganan Kekerasan Perempuan oleh Badan Pemberdayaan Perempuan Perlindungan Anak dan

\section{Keluarga Berencana Kota Semarang}

Pemerintah Kota Semarang dalam hal menangani masalah kesejahteraan sosial salah satunya adalah kekerasan terhadap perempuan didelegasikan kepada BP3AKB yang mempunyai tugas pokok melaksanakan penyusunan dan pelaksanaan kebijakan daerah di bidang pemberdayaan perempuan, perlindungan anak, keluarga berencana dan keluarga sejahtera.

Penanganan kekerasanperempuan di Badan Pemberdayaan Perempuan Perlindungan Anak dan Keluarga Berencana (BP3AKB), dalam hal ini BP3AKB memiliki tugas dalam pembinaan Pusat Pelayanan Terpadu korban kekerasan perempuan, fasilitasi dan pelaksanaan tugas.

Apabila BP3AKB sebagai fasilitatormaka Pusat Pelayanan Terpadu sebagai pelaksana penanganan korban kekerasan diKota Semarang yang terbagi atas 10 Pusat Pelayanan Terpadu yang 
tersebar di Kecamatan.PPT ditingkat Kecamatan memberikan pelayanan langsung kepada korban baik medis, psikologis, hukum dan reintegrasi sosial. Penanganan medis bagi perempuan korban kekerasan masih bergantung pada fasilitas penanganan medis untuk korban kekerasan yang disediakan Pemerintah Provinsi seperti RSUD Tugurejo Semarang dengan kualitas penanganan kelas 1, RSUD Ketileng Kota Semarang, dan Puskesmas di empat Kecamatan. Pusat Pelayanan Terpadu SERUNI dibagi menjadi 3 Divisi yaitu Pelayanan, Advokasi, dan Komunikasi, informasi dan Edukasi.

Dalam penanganan korban kekerasan terhadap perempuan di Pusat Pelayanan Terpadu ini kegiatan yang dilakukan yaitu berkoordinasi antara pihak - pihak yang terkait, yaitu Rumah Sakit, Pengadilan Agama dan juga Kepolisian. Kader pendamping memberikan informasi kepada korban tentang proses mengurus berkas dan juga sebagai mediator, lalu kemudian setelah kasus selesaipun kader pendamping masihterus memantau korban tentang bagaimana keadaan korban setelah kasus selesai dan juga perkembangannya.

Kegiatan yang dilakukan dalam penanganan korban kekerasan terhadap perempuan adalah pendampingan terhadap korban yaitu mulai dari
Konselling untuk menentukan pilihan apa yang akan diambil oleh korban, apakah akan damai atau tidak,kemudian memberikan informasi tentang tahapan dalam pengurusan berkas misalnya ke Pengadilan Agama atau mengantarkan korban ke Rumah Sakit dan Psikolog. Setelah proses berlangsung, pendamping juga sebagai mediator ,dimana antara pihak yang berkonflik dilakukan pendekatan dan saling berbicara dan mendengarkan satu sama lain sehingga diperoleh titik temu kesepakatan bersama atau yang disebut SKB (Surat Keputusan Bersama), kemudian setelah konflik selesai pendamping juga masih melakukan pemantauan, yaitu dengan masih berkomunikasi dengan korban untuk menanyakan bagaiama keadaan korban setelah kasusnya selesai.

Keterlibatanstakeholder

dalam penanganan kekerasan terhadap perempuan di Kota Semarang

Badan Pemberdayaan Perempuan Perlindungan Anak dan Keluarga Berencana (BP3AKB) dalam menangani korban kekerasan terhadap perempuan tidak bekerja sendiri, terjalinkerjasama dariberbagaiinstansi lain yaitu dengan Rumah Sakit, Puskesmas, Kepolisian, Lembaga Bantuan Hukum, Badan Pemberdayaan Masyarakat, Dinas 
Pendidikan, dan Lembaga Swadaya Masyarakat (LRC-KJHAM, YSS, LBH). karena perlu berkoordinasi dengan pihakpihak tersebut.

Bagan 2 Alur Penanganan, Pendampingan dan Pencegahan Korban Kekerasan terhadap Perempuan pada PPT Kota Semarang
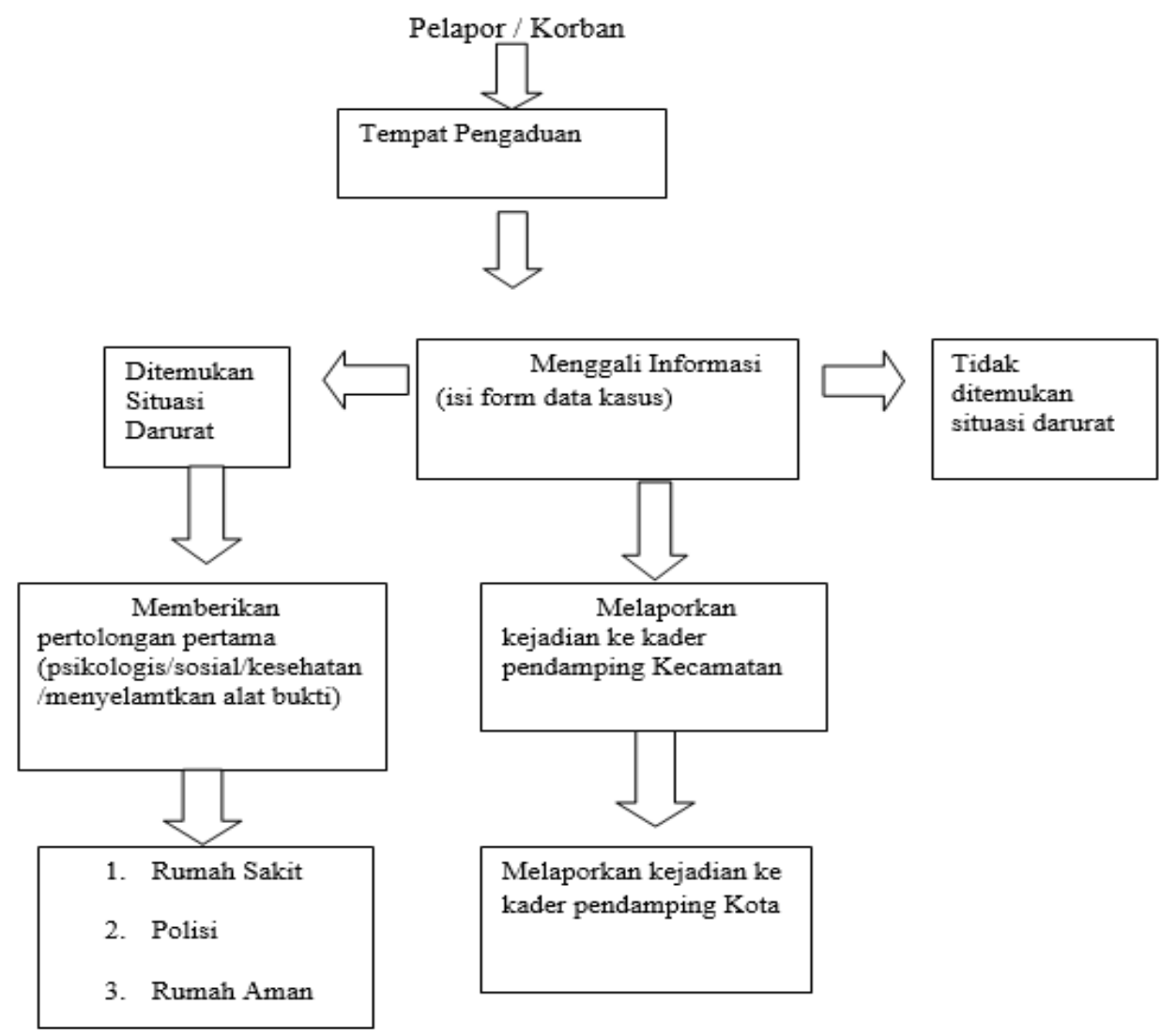

Sumber : Pusat Pelayanan Terpadu SERUNI

Keterlibatan yang terjalin antara

Badan Pemberdayaan Perempuan

Perlindungan Anak dan Keluarga Berencana (BP3AKB) Kota Semarang dengan stakeholder sudah baik, BP3AKB membagi tugas dan kewenangan antara pihak-pihak yang berhubungan sesuai dengan kebutuhan masing - masing korban kekerasan dan dalam penanganan terhadap korban terjalin koordinasi yang baik antara stakeholder namun dalam menyelesaikan suatu perkara masih memerlukan waktu yang cukup lama
Faktor-Faktor yang berpengaruh dalam Pelayanan terhadap Penanganan Kekerasan Perempuan di Kota Semarang

a. Kesesuaian visi dan misi dengan kondisi

Kesesuaian dari visi dan misi dengan kondisi, tantangan dan kebutuhan daerah merupakan hal yang sangat penting. Kesesuaian tersebut akan menjadi faktor yang memudahkan dan melancarkan pelaksanaan penanganan kekerasan 
terhadap perempuan di Kota Semarang sehingga terwujudnya kesejahteraan masyarakat yang berdaya saing dalam hal ini adalah penghapusan kekerasan terhadap perempuan khususnya. Dengan kesesuaian visi misi dan tujuan dapat menyatukan langkah untuk melakukan upaya penanganan yang optimal.

b. Kualitas SDM yang memadai

Kualitas sumber daya manusia padaPusat Pelayanan Terpadu Seruni Kota Semarang khusunya pada upaya pendampingan korban kekerasan sudah cukup memadai . Hal ini sangat mendukung dalam setiap pelaksanaan kegiatan penanganan kekerasan perempuan di Kota Semarang. Pengalaman para kader pendamping dapat menjadi pendukung dalam pendampingan-pendampingan korban yang lain. Para kader pendamping telah terbiasa menghadapi karakteristik orang yang berbeda-beda dan juga berbagai macam kasus. Sehingga dalam pendampingan para kader telah mengerti harus menggunakan model pendekatan seperti apa kepada para korban.

c. Kuantitas SDM yang kurang memadai Secara kuantitas, jumlah sumber daya manusia di Pusat Pelayanan Terpadu Seruni Kota Semarang masih kurang memadai. Pusat Pelayanan
Terpadu penanganan kekerasan berbasis gender terdapat di 10 Kecamatan di Kota Semarang, namun jumlah kader pendamping masih belum mencukupi. Seringkali tidak ada petugas yang menjaga PPT, sehingga PPT seringkali kosong.

Dalam pengelolaan PPT Seruni Kota Semarang yang menangani kekerasan terhadap perempuan ini sumber daya manusia merupakan motor penggerak jalannya suatu pelayanan. Jumlah petugas pada PPT Seruni hanya 16 orang yang terbagi pada 10 Kecamatan, berbanding terbalik dengan banyaknya jumlah kekerasan perempuan di Kota Semarang. Kondisi tidak adanya petugas yang siap siaga menjaga di PPT, jika tidak segera diatasi kondisi seperti ini maka kurangnya kuantitas SDM akan berdampak pada pelaksanaan program kegiatanpendampingan dan penyelesaian kasus kekerasan.

d. Komitmen Pusat Pelayanan Terpadu Seruni Kota Semarang dalam memberikan pelayanan maksimal kepada korban kekerasan

Dalam proses penyelenggaraan pelayanan kepada publik, Pemerintah Kota Semarang mempunyai komitmen untuk mensejahterakan masyarakat terutama dalam penghapusan 
kekerasan terhadap perempuan di Kota Semarang. Bentuk komitmen Pemerintah dalam hal ini adalah tersebarnya Pusat Pelayanan Terpadu untuk menangani korban kekerasan berbasis gender Kota Semarang yang tersebar di 10 Kecamatan. Dan juga melaksanakan sosialisasi kepada masyarakat tentang penghapusan kekerasan terhadap perempuan, dan adapula sosialisasi bagi para kader pendamping agar mereka dapat dengan baik mendampingi para korban kekerasan. Pusat Pelayanan Terpadu bagi kekerasan terhadap perempuan juga memiliki Standar Operasional Prosedur (SOP) dan Mekanisme Kerja Pelayanan yang didalamnya memuat secara teknis bagaimana penanganan korban kekerasan yang dilakukan oleh PPT Seruni Kota Semarang

e. Dukungan dari Pemerintah khususnya dalam membagi sarana pendukung PPT menjadi 3 Divisi

Keputusan Walikota Semarang tanggal 6 Januari 2011 No. 463/05/2011 memutuskan untuk membagi pelayanan menjadi 3 Divisi yaitu Divisi Advokasi, Divisi Pelayanan, dan Divisi Komunikasi, Informasi dan Edukasi. Selain 3 Divisi ada Sekretariat Tetap yang merupakan sarana pendukung untuk lancarnya semua program dan kegiatan divisidivisi yang ada.

f. Minimnya anggaran pendampingan

Minimnya anggaran Dinas pada saat pendampingan korban yang diberikan oleh BP3AKB pada setiap kader pendamping menjadikan penananganan kurang maksimal. Pemberian anggaran yang diberikan oleh BP3AKB ke Pusat Pelayanan Terpadu Seruni yang kemudian diberikan kepada setiap kader sebagai anggaran pendampingan korban kekerasan terhadap perempuan berupa biaya transportasi selama proses pendampingan, biaya untuk pengurusan berkas - berkas terkait kasus korban, dan biaya pengobatan korban.

g. Sarana dan Prasarana Pusat Pelayanan Terpadu Seruni yang kurang memadai Infrasturuktur yang ada Pusat Pelayanan Terpadu Serunidikatakan kurang memadai, sehingga kegiatankegiatan penanganan tidak bisa berjalan maksimal. PPT Seruni Kota Semarang terdapat pada 10 Kecamatan yang tersebar di Kota Semarang, namun tempatnya masih menumpang.PPT Srikandi misalnya, tempatnya masih menumpang pada Puskesmas Banyumanik, dan ruanganpun sempit dan tidak ada 
pesawat telephon.Sedangkan

infrastruktur saat

kegiatan

pendampingan maupun sosialisasi di lapangan masih menggunakan kendaraan pribadi para kader pendamping.

h. Kurangnya kesadaran dan peran serta masyarakat dalam penghapusan kekerasan terhadap perempuan

Ketidakperdulian masyarakat terhadap apa yang terjadi disekitar mereka termasuk terjadinya tindak kekerasan terhadap perempuan dilingkungan sekitar menjadi penghambat dalam penanganan kekerasan terhadap perempuan. Mereka tidak perduli dan tidak mau tahu tentang tindak kekerasan yang terjadi.

Rendahnya kesadaran masyarakat dalam penghapusan kekerasan juga tercermin dari masih banyak masyarakat yang merasa takut melaporkan kekerasan yang dialaminya karena malu orang lain mengetahui apa yang dialaminya.

i. Karaktersistik pelaku kekerasan yang sulit ditangani

Kebanyakan pelaku kekerasan terhadap perempuan terutama pelaku yang merupakan orang terdekat korban contohnya keluarga atau suami, mereka menganggap bahwa apa yang mereka lakukan kepada korban merupakan hak mereka dan orang lain tidak pantas untuk ikut campur. Sehingga hal tersebut yang menyebakan konflik tidak dapat terselesaikan dengan cepat dan mudah.

j. Kota Semarang sebagai tempat tujuan para pencari kerja

Kota Semarang merupakan salah satu Kota besar yang cukup strategis yang berbatasan dengan kabupaten Ungaran, Demak, dan Kendal. Ini merupakan salah satu faktor seseorang untuk mengadu nasib di Kota Semarang. Penyediaan lapangan kerja dan kebutuhan rumah yang tidak dapat difasilitasi oleh Pemerintah menyebabkan masyarakat berada pada keadaan ekonomi yang rendah.Keadaan semacam itu menyebabkan masyarakat menjadi rentang terjadinya tindak kekerasan khususnya perempuan. Perempuan dieksploitasi agar pelaku mendapatkan pendapatan untuk kehidupan sehari hari.

\section{SIMPULAN}

Kegiatan yang dilakukan dalam pelayanan korban kekerasan terhadap perempuan adalah pendampingan terhadap korban yaitu mulai dari Konselling untuk menentukan pilihan apa yang akan diambil oleh korban,kemudian memberikan informasi tentang tahapan 
dalam pengurusan berkas misalnya ke Pengadilan Agama atau mengantarkan korban ke Rumah Sakit dan Psikolog.

Setelah proses berlangsung, pendamping juga melakukan mediasi,dimana antara pihak yang berkonflikdilakukan pendekatan dan saling berbicara dan mendengarkan satu sama lain sehingga diperoleh titik temu kesepakatan bersama atau yang disebut SKB (Surat Keputusan Bersama), setelah konflik selesai pendamping juga masih melakukan pemantauan, yaitu dengan masih berkomunikasi dengan korban untuk menanyakan bagaimana keadaan korban setelah kasusnya selesai.

Berikutkondisipelayanankorban kekerasanterhadapperempuan di Kota Semarang, Pertama, Pelayanan pada Pusat Pelayanan Terpadu SERUNI masih belum optimal, dapat dilihatdari masih banyaknya jumlah angka kekerasan terhadap perempuan di Kota Semarang dan bahkan cenderung meningkat dari tahun ketahun, hal lain yaitu jumlah kader pendamping di Pusat Pelayanan Terpadu Seruni yang masih kurang, anggaran penanganan yang kurang serta kondisi sarana dan prasarana dalam pelaporan dan pendampingan belum cukup baik. Kedua, BP3AKB dalam menangani korban kekerasan terhadap perempuan bekerjasama dengan instansi lain seperti Rumah Sakit, Puskesmas,
Kepolisian, Lembaga Bantuan Hukum, Badan Pemberdayaan Masyarakat, Dinas Pendidikan, dan Lembaga Swadaya Masyarakat. Ketiga, Faktor yang mempengaruhi penanganan kekerasan terhadap perempuan di Kota Semarang yaitu kuantitas SDM yang kurang memadai, komitmen Pusat Pelayanan Terpadu Seruni Kota Semarang dalam memberikan pelayanan maksimal kepada korban kekerasan, dukungan dari Pemerintah khususnya dalam membagi sarana pendukung PPT menjadi 3 Divisi, minimnya anggaran pendampingan, sarana dan prasarana Pusat Pelayanan Terpadu Seruni yang kurang memadai, kurangnya kesadaran dan peran serta masyarakat dalam penghapusan kekerasan terhadap perempuan, karaktersistik pelaku kekerasan yang sulit ditangani, Kota Semarang sebagai tempat tujuan para pencari kerja.

Banyaknya jumlah angka kekerasan terhadap perempuan di Kota Semarang dan bahkan cenderung meningkat dari tahun ketahunpeneliti memberikan saran, sebagai berikut: Pertama, Meningkatkan jumlah anggaran pendampingan untuk korbandari BP3AKBkepada Pusat Pelayanan Terpadu Seruni. BP3AKB sudah menetapkan anggaran untuk satu korban yang didampingi, padahal masing-masing korban memiliki kebutuhan yang berbeda-beda. 
Kedepannya anggaran supaya dapat diperbesar sesuai dengan yang dibutuhkan masing-masing korban.Kedua, Pengoptimalan Kualitas dan Kuantitas SDM pada BP3AKB dan Pusat Pelayanan Terpadu Seruni.Ketiga, Menyediakan sarana dan prasarana yang memadai. Sarana dan prasarana yang telah ada sebisa mungkin dapat digunakan sebaik - baiknya dan sarana prasarana yang belum ada perlu segera disediakan agar dalam memberikan pelayanan terhadap korban dapat berjalan dengan maksimal,seperti : telephone, komputer, meja dan kursi, papan pengumuman,dll. Keempat, Menyediakan informasi yang lengkap dan mudah tentang kekerasan terhadap perempuan kepada masyarakat. Perlunya informasi kepada masyarakat supaya masyarakat mengetahui bagaimana cara mencegah terjadinya tindak kekerasan terhadap perempuan maupun cara melapor apabila mengalami atau melihat tindak kekerasan.Hal tersebut dapat dilakukan melalui sosialisasi, penyebaran pamflet ataupun lewat pembuatan website.

\section{DAFTAR PUSTAKA}

Aime Heene, dan tim. 2010. Manajemen Strategik Keorganisasian Publik. Bandung:Refika Aditama
Aziz, Aina Rumiati. 2006. Perempuan Korban di Ranah Domestik.www.Indonesia.com

Azwar, Saifuddin. 1998. Metode Penelitian. Yogyakarta: Pustaka Pelajar.

Carwoto. 2007. Mengungkap dan Mengeliminasi Kekerasan terhadap Isteri dalam Menggugat Harmoni.Yogyakarta: Rifka Anisa

Damadi, Damai. 2009. Administrasi Publik.Yogyakarta: Laksbag Pressindo

Djannah, Fathul. 2002. Kekerasan Terhadap Istri. Yogyakarta: LKIS

Fathoni, Abdurrahmat. 2006. Manajemen Sumber Daya Manusia.Jakarta: PT. Rineka Cipta

Keban, Yeremias. 2008. Enam Dimensi Strategis Administrasi Publik. Yogyakarta Gava Media.

Moleong, Lexy J. 2007.Metode Penelitian Kualitatif. Bandung: PT Remaja Rosdakarya.

Nadia, Ita F. 2007.Suara Perempuan Korban Tragedi 65. Yogyakarta: Galang Press

Purwandari, KristiE. 2002. Kekerasan Terhadap Perempuan.Jakarta: Gramedia Pustaka Utama.

Salusu, J. 2000. Pengambilan Keputusan Stratejik untuk organisasi. Jakarta: Grasindo

Singarimbun, Masri dan Efendi, Sofyan. 1995. Metode Penelitian Survai.Jakarta: LP3ES Indonesia 
Sugiyono. 2007. Metode Penelitian Kuantitatif Kualitatif dan $R \& D$. Bandung: Alfabeta.

Tangkilisan, Hessel Nogi. 2003.Manajemen Modern Untuk Sektor Publik. Yogyakarta: Baliurang

Wibisono, Dermawan. 2006. Manajemen Kinerja (Konsep, Desain dan Teknik Meningkatkan Daya Saing Perusahaan ). Jakarta: Erlangga.

Wirawan. 2009. Evaluasi Kinerja Sumber Daya Manusia. Jakarta: Salemba Empat

Peraturan Mentri Dalam Negri No. 15 Tahun 2008 tentang Pedoman Pelaksanaan Pengarustamaan Gender di Daerah

Rencana Pembangunan Jangka Menengah Nasional 2010 - 2014

Undang - Undang No. 9 Tahun 2000 tentang Pengarusutamaan Gender dalam Pemberdayan Nasional

Undang - Undang No. 23 Tahun 2004 tentang Penghapusan Kekerasan dalam Rumah Tangga

Surat Keputusan Gubernur Jateng No. 76 Tahun 2006 tentang Pembentukan Komisi Perlindungan Perempuan dan Anak

Surat Keputusan Walikota Semarang No. 463. 05/ 112 Tahun 2007 tentang Pembentukan Pusat Pelayanan Terpadu Seruni dan Instruksi Walikota Semarang No. 463/ 13/ 2007

Undang - Undang No.21 Tahun 2007 tentang Pemberantasan Tindak Pidana Perdagangan Orang

Undang - Undang No. 25 Tahun 2009 tentang Pelayanan Publik 